\title{
A Study of Ozone Anomaly of 2011 in the Northern Hemisphere Based on Aura Satellite Data
}

\author{
Valentine B. Kashkin and Tatiana V. Rubleva* \\ Siberian Federal University \\ 79 Svobodny, Krasnoyarsk, 660041, Russia
}

Received 17.03.2017, received in revised form 29.05.2017, accepted 16.07.2017

In this work we have studied the appearance of analogue of the Antarctic ozone hole in the Northern hemisphere in March 2011. Possible reasons of this phenomenon were the low temperature in the polar region and intense solar flares. The solar activity led to changes in the atmospheric circulation. As a result, in the stratosphere for a while have any rotating circumpolar vortex in the form of a ring in mid-latitudes and low ozone content in the polar region. Our studies revealed a redistribution of ozone mass between the inner and outer part of the vortex with decreasing the total ozone content in the inner part and increases in the outer. A model of the formation of the circumpolar vortex based on atmospheric physics is proposed.

Keywords: ozone hole, redistribution of ozone, physical model of circumpolar vortex.

Citation: Kashkin V.B., Rubleva T.V. A study of ozone anomaly of 2011 in the northern hemisphere based on aura satellite data, J. Sib. Fed. Univ. Eng. technol., 2017, 10(6), 828-834. DOI: 10.17516/1999-494X-2017-10-6-828-834.

(C) Siberian Federal University. All rights reserved

* Corresponding author E-mail address: tvrubleva@ksc.krasn.ru 


\title{
Озонная аномалия 2011 г. в Северном полушарии, по данным спутника aura
}

\author{
В.Б. Кашкин, Т.В. Рублева \\ Сибирский Федеральный университет \\ Россия, 660041, Красноярск, пр. Свободный, 79
}

\begin{abstract}
Изучен аналог антарктической озоновой дыры, возникший в Северном полушарии в марте 2011 года. Возможной причиной появления озоновой дыры была низкая температура в полярной области и интенсивные солнечные вспышки. Повышение солнечной активности привело к изменению в атмосферной циркуляции. В результате в стратосфере на некоторое время возник вращающийся циркумполярный вихрь в виде кольца в средних широтах и с низким содержанием озона в полярных. Наши исследования выявили перераспределение масс озона между внутренней и наружной частями вихря с уменьшением общего содержания озона во внутренней части и увеличением в наружной. Предлагается модель формирования ииркумполярного вихря, основанная на законах физики атмосферы.
\end{abstract}

Ключевые слова: озоновая дыра, перераспределение озона, физическая модель ичиркуполярного вихря.

The Antarctic Ozone Hole (AOH) has been observed for 30 years. It occurs every year between the months of September and December. The AOH is the central part of the circumpolar vortex (CV), which consists of a ring with elevated total ozone, reaching 400 Dobson units (DU). The diameter of the ring is about $9000 \mathrm{~km}$, and its rotational speed is $10-20 \mathrm{~m} / \mathrm{s}$. Total ozone (TO) inside the ring sometimes drops to 80-90 DU. Global satellite data on the ozone layer available at the NASA site [1] have provided the basis for thorough research of the $\mathrm{AOH}$ and other similar atmospheric phenomena. They were used to develop a physical model of the formation of the AOH in the Southern Hemisphere [2].

Atmospheric structure similar to AOA, previously has not been observed in the Northern hemisphere. The conditions here are quite different from those in the Southern Hemisphere: the area of land surface is considerably larger, the total ozone concentration is higher, and the zonal velocity of ozone masses is significantly lower. Near the North Pole, as a rule, there is no area with extremely low temperatures, such as at the South Pole; the lowest temperature is observed over the continents (North America, Asia). The North hemisphere and Arctic ozone annual maximum falls in the middle of March.

For the 35 years of satellite monitoring, the only atmospheric phenomenon similar to the circumpolar vortex of the Southern Hemisphere was observed in the Arctic between March 5 and April 6, 2011 (Fig. 1). The inner part of the vortex ring, with a decreased TO, stretched between Canada and the Taimyr Peninsula. The "dip" in the center of CV in Fig. 1 is not a classical ozone hole, as the TO inside the ring is higher than the conditional threshold of 220 DU [3].

The phenomenon was discussed by some authors based of atmospheric chemistry approach $[4,5]$. In this study we are focusing on atmospheric physics.

A possible reason for this anomaly might be weak planetary wave driving in February preceded cold conditions in the polar lower stratosphere in March (temperature below $196 \mathrm{~K}$ ) [4, 6]. A significant solar activity was observed in February and March 2011 [7, 8]. The spatial distribution of the atmosphere

$$
-829-
$$


pressure variations associated with solar activity and cosmic rays seems to be determined by their influence on the circulation of the atmosphere [9]. Because of this air flow for some time was curled up in the ring, and there was a dramatic increase of the zonal angular velocity in polar region $\left(60^{\circ}-85^{\circ} \mathrm{N}\right)$ up to $20 \mathrm{~m} / \mathrm{s}$. The vortex rotation was unstable, its shape changed during the period. The planetary wave apparently destroyed the Arctic polar vortex in April 6.

The graph of the angular velocities of the zonal ozone mass transfer $\bar{W}$ in the stratosphere, $60^{\circ}-65^{\circ}$ $\mathrm{N}$, is for the period between March 1 and April 11, 2011 (Fig. 2). The graph was plotted following the procedure described elsewhere [10]. The procedure based on a comparison of global digital space-born TO maps for consecutive two days. In the period, minimal TO values (below $250 \mathrm{DU}$ ) were observed north of Canada for 27 days [3]. For one week at the end of March, TO dropped to 220-230 DU, and the degree of polar ozone loss was unprecedented.

In March 2011, the average zonal angular velocity of ozone mass transfer $\bar{W}$ in the polar region was $11^{\circ}$ per day. That was almost twice higher than $\bar{W}=5.6^{\circ}$ per day, the value characteristic of March during 1997-2004 [10]. Peak velocity was near $20^{\circ}$ per day on 10 March.

In spring 2011, a vast anticyclone was formed in the polar and adjacent regions of the Northern Hemisphere; the atmospheric pressure in the atmosphere close to the pole increased considerably. The air currents began to move from the pole to middle latitudes, in all directions.

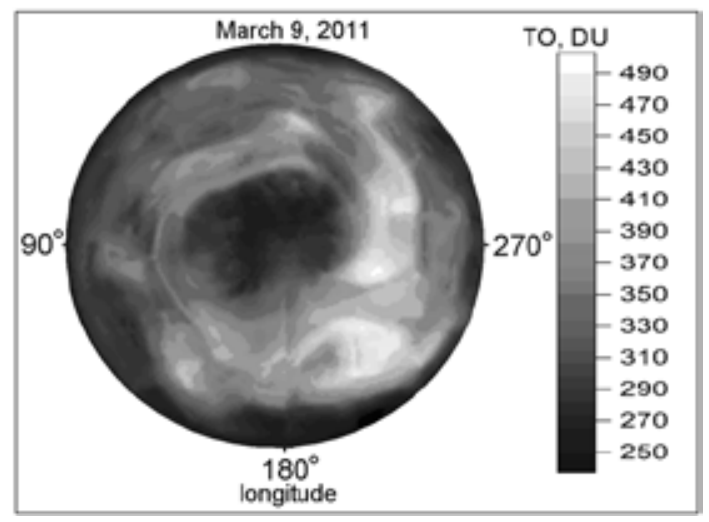

Fig. 1. Circumpolar vortex in the Northern Hemisphere in March 9, 2011

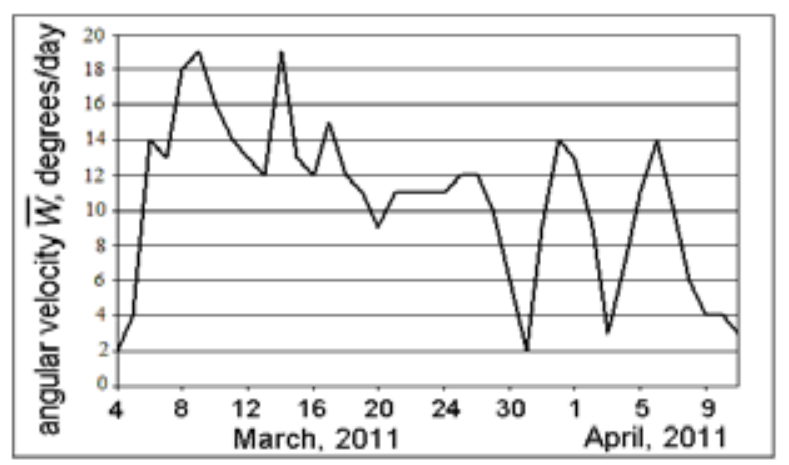

Fig. 2. Variations in the angular velocity in the $60^{\circ}-65^{\circ} \mathrm{N}$ region in the spring of 2011 


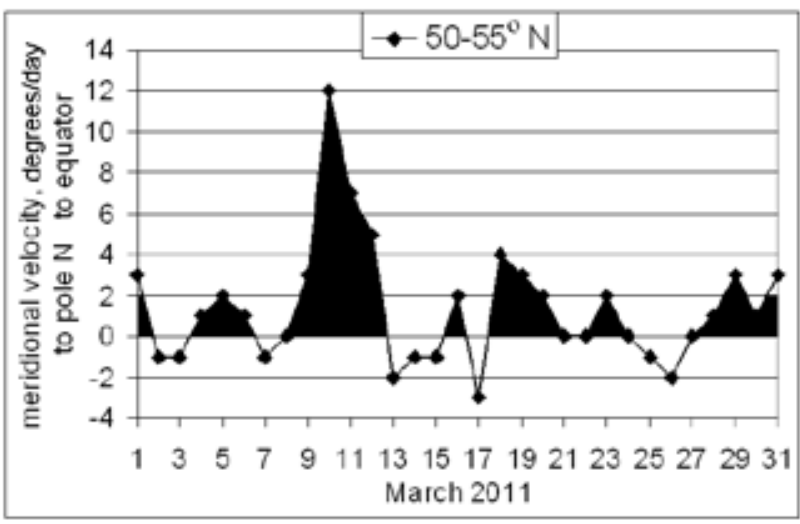

Fig. 3. Meridional velocity in March 2011. Black color corresponds to outflow of ozone from the polar latitudes to middle latitudes

In the middle stratosphere, the air currents began to move along with the ozone from tropical latitudes to middle and polar latitudes (principle of Brewer-Dobson) [2]. One can see Fig. 3, which shows meridional velocity component of the ozone mass in the latitude of 50-55 in March. The movement from the tropics towards the pole in Fig. 3 corresponds to negative values of speed. But the outflow of ozone from the polar latitudes to middle latitudes (black color) dominates in March.

The deflecting force of the Earth's rotation (Coriolis force) hampers these currents and deflects them to the east; thus, the currents move along a circular path. Under these conditions, the following is valid [2]:

$$
m \frac{V^{2}}{R_{\varphi}}+\frac{\Delta p}{\Delta r}=2 \Omega V m \sin \varphi
$$

The left-hand side also contains pressure gradient $\frac{\Delta p}{\Delta r}$ in the $r$ direction from the pole. The righthand side of (1) contains the Coriolis force; here $\Omega=7.2921 \cdot 10^{-5}$ radians $/ \mathrm{s}$ - the angular speed of Earth's rotation.

The Coriolis force and centrifugal force depend on latitude $\varphi$; at a certain latitude, $\varphi_{0}$, the Coriolis force has the highest hampering effect. It should be expected that air masses (including ozone) transferred from the polar region would concentrate close to this latitude, and a CV ring would develop. To find latitude $\varphi_{0}$, let us calculate a $\varphi$ derivative from (1) and equate it to zero

$$
m \frac{V^{2} \sin \varphi}{R_{E} \cos ^{2} \varphi}-2 \Omega V m \cos \varphi=0 .
$$

Expression (2) is transformed into

$$
x^{3}+3 p x+2 q=0, x=\cos ^{2} \varphi, p=\frac{V^{2}}{12 \Omega^{2} R_{E}^{2}}, q=-\frac{V^{2}}{8 \Omega^{2} R_{E}^{2}} .
$$

Taking into account that discriminant $D=p^{3}+q^{2}>0$ and $p^{3}<<q^{2}$, we obtain:

$$
-831-
$$




$$
\varphi_{0}=\arccos \left[2 \sqrt[3]{\frac{V}{2 \Omega R_{E}}}\right] .
$$

On March 9, $\bar{W}=19^{\circ}$ per day, which corresponds to $V \approx 18 \mathrm{~m} / \mathrm{s}$. Calculations based on formula (3) show that the highest TO is at latitude $\varphi_{0}=59^{\circ}$. The radius of the ring in Fig. 1, along the midline, is $3280 \mathrm{~km}$. On the other hand, the latitude of the TO maximum can be found from the satellite data, using TO zonal means offered in [1].

Zonal means are TOC daily values averaged over the longitudes between $-179.5^{\circ}$ and $179.5^{\circ}$, in the 5-degree latitude range, e.g., between $52.5^{\circ}$ and $57.5^{\circ}$. The graphs of zonal means for three days of the spring of 2011 are shown in Fig. 4. The curve for March 9 demonstrates that the highest TO be at latitude of $60^{\circ}$, which is close to the latitude $\varphi_{0}$ determined above. The part of the graph above 300 DU describes the ring profile averaged over longitudes. Analysis of the curve for March 9 suggests the redistribution of ozone between the inner part of the $\mathrm{CV}$ and the ring: the decrease in the ozone concentration in the inner part and the increase in the ring - an event similar to that occurring in the Southern Hemisphere in spring [2].

If subsequent events had developed according to the Southern Hemisphere scenario, the rotational speed of ring $V$ would have decreased gradually, and ozone would have moved from the ring to the polar region. However, in April, the ozone anomaly shifted to Eurasia (Fig. 5). A possible reason for that could be the warming, which, according to [12], occurred in late March. Relatively low TO was observed above a vast area, between Arkhangelsk and Yakutsk and between Yekaterinburg and Dixon, the total ozone dropping by $25-30 \%$.

The second warming occurred in early April. As can be seen from Fig. 5, on April 10, TO was the highest at the pole, while the lowest TO values had shifted southward. By that time, the ozone anomaly had shrunk considerably, covering part of the northern West Siberia and the Krasnoyarsk Territory. In these regions, the lowest TO value reached 220 DU; that was lower than the minimal TO in the Arctic in mid-March, a possible reason being ozone chemical destruction.

V.V. Zuev et al [13] found that destruction of the stratospheric ozone layer in Siberia in April 2011, had been caused by the eruption of Merapi Volcano in Indonesia in November 2010. In the following

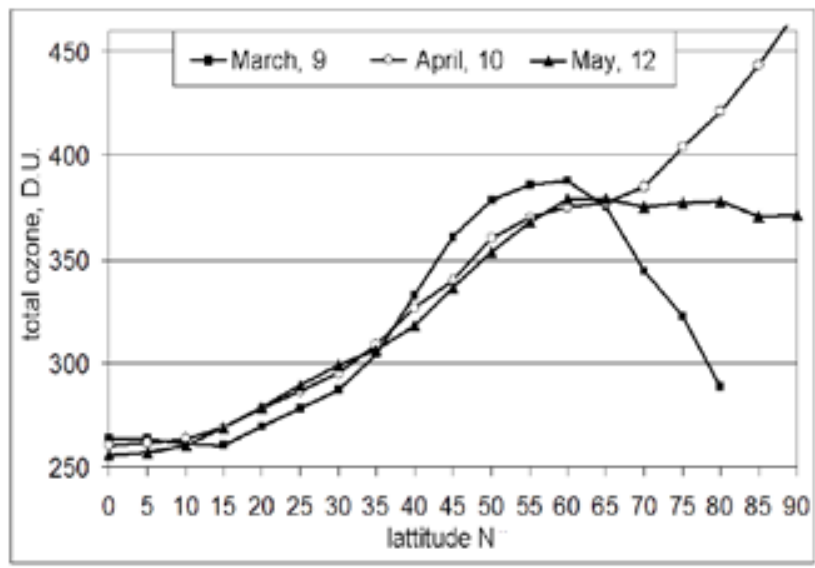

Fig. 4. Latitude dependence of zonal means 


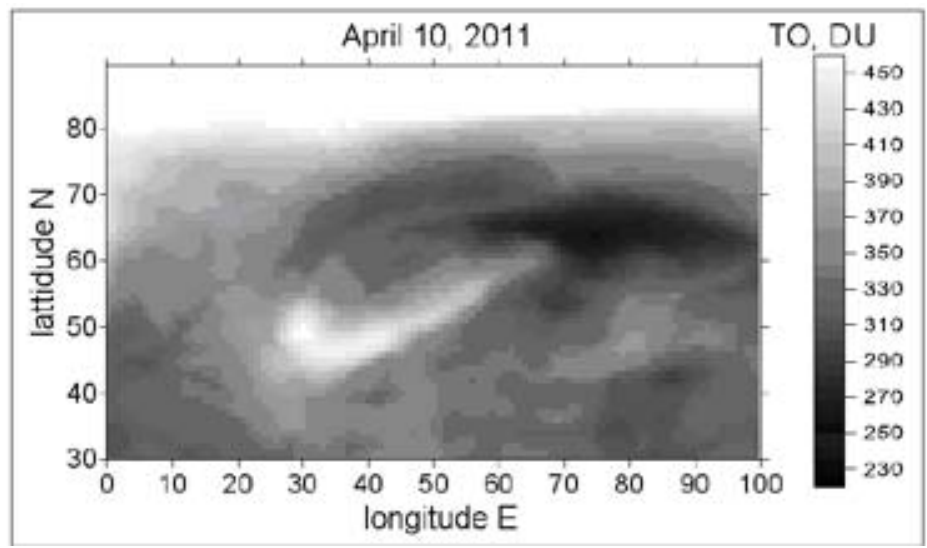

Fig. 5. Ozone anomaly shifting to Siberia

months of 2011, TO values above the greater part of Russia and Western Europe were lower than their long-term annual averages.

Our study showed that natural physical factors had contributed considerably to the development of the North Hemisphere ozone anomaly 2011.

\section{References}

[1] [Internet resource]. Access mode: URL: ftp://jwocky.gsfc.nasa.gov/pub/omi/data

[2] Кашкин В.Б. Исследование антарктического озоновогоциркумполярного вихря с использованием данных спутникового дистанционного зондирования, Журнал СФУ. Техника и технологии, 2015, 2 (8), 238-246 [Kashkin V.B. A study of the Antarctic ozone circumpolar vortex using satellite remote sensing data, J. Sib. Fed. Univ. Eng. Technol, 2015, 2, 238-246 (in Russian)]

[3] Кашкин В.Б., Рублева Т.В., Хлебопрос Р.Г. Арктическая озонная аномалия 2011 года, Тезисы докладов ХVII Всероссийского симпозиума Сложные системы в экстремальных условиях, Красноярск: ФГБУН КНЦ, 2014, 22 [Kashkin V.B., Rubleva T.V., Khlebopros R.G. The Arctic ozone anomaly of 2011, Abstract for the 27th Russian Symposium Complex systems in extreme conditions, Krasnoyarsk, 2014, 22 (in Russian)]

[4] Manney G.L., Santee M.L., Rex M. et al. Unprecedented Arctic ozone loss in 2011, Nature, 2011, 478 (7370), 469-475. doi: 10.1038/nature10556.

[5] B.-M. Sinnhuber, G. Stiller, R. Ruhnke, T. et al. Arctic winter 2010/2011 at the brink of an ozone hole, Geophys. Res. Lett. , 2011, 38, L24814, doi:10.1029/2011GL049784.

[6] Hurwitz M.M., Newman P.A. and Garfinkel C.I. The Arctic vortex in March 2011: a dynamical perspective, Atmos. Chem. Phys., 2011, 11, 11447-11453, doi:10.5194/acp-11-11447-2011

[7] [Internet resource]. Access mode: URL: http://www.tesis.lebedev.ru/info/tesis_20110301.php

[8] [Internet resource]. Access mode: URL: http://www.swpc.noaa.gov/products/goes-x-ray-flux

[9] Veretenenko S., Ogurtsov M. Regional and temporal variability of solar activity and galactic cosmic ray effects on the lower atmosphere circulation, Adv. Space Res., 2012, 49, 770-783.

[10] Кашкин В.Б., Рублева Т.В. Зональное движение масс озона в нижней стратосфере по спутниковым данным, Оптика атмосферы и океана, 2014, 27 (9), 826-832. [Kashkin V.B., 
Rubleva T.V. Zonal movement of ozone masses in the lower stratosphere based on satellite data, Atmos. Ocean. Optics, 2014, 27 (9), 826-832 (in Russian)]

[11] Кашкин В.Б., Рублева Т.В. Изучение зональной циркуляции озона в нижней стратосфере средних широт на основе спутниковых данных, Материалы XX Международного симпозиума Оптика атмосферы и океана. Физика атмосферы, Новосибирск, 2014, 143-147 [Kashkin V.B., Rubleva T.V. A study of zonal circulation of ozone in the lower stratosphere of middle latitudes based on satellite data, Proceedings of the $20^{\text {th }}$ International Symposium Atmospheric and Oceanic Optics. Physics of the atmosphere, Conference D Physics of the atmosphere, Novosibirsk, 2014, 143-147 (in Russian)]

[12] Ананьев Л.Б., Звягинцев А.М., Кузнецова И.Н., Нахаев М.И. Особенности общего содержания озона и циркуляции в нижней стратосфере в зимне-весенний период 2011 года, Труды Гидрометцентра России, М.: Гидрометеоиздат, 2012, 347, 44-60 [Ananyev L.B., Zvyagintsev A.M., Kuznetsova I.N., Nakhaev M.I. Total ozone concentration and ozone circulation in the lower stratosphere in winter and spring 2011, Proceedings of the Russian Meteorological Service, Moskow, 2012, 347, 44-60 (in Russian)]

[13] Зуев В.В., Зуева Н.Е., Савельева Е.С. и др. О роли извержения вулкана Мерапи в аномальном понижении ОСО над Томском в апреле 2011 г., Оптика атмосферы и океана, 2015, 28 (12), 1090-1094 [Zuev V.V., Zueva N.E., Savelyeva E.S. et al. On the role of the Merapi Volcano eruption in the abnormal decrease in TOC above Tomsk in April 2011, Atmos. Ocean. Optics, 2015, 28 (12), 1090-1094 (in Russian)] 